\title{
Production of the Secondary Metabolite Cyanide by Extracts of Chromobacterium violaceum
}

\author{
By ALAN W. BUNCH† AND CHRISTOPHER J. KNOWLES* \\ Biological Laboratory, University of Kent, Canterbury, Kent CT2 7NJ, U.K.
}

(Received 1 April 1982)

\begin{abstract}
The ability of cell-free extracts of Chromobacterium violaceum to form cyanide has been investigated. For maximal activity, extracts had to be prepared from bacteria harvested at the end of growth and stored under anaerobic conditions in the presence of dithiothreitol. Glycine was the substrate for cyanide formation by extracts and an electron acceptor such as phenazine methosulphate was required. Radiolabelling studies confirmed that cyanide was produced by decarboxylation of glycine. Formaldoxime, glyoxylic acid oxime, oxamic acid and $\mathrm{N}$ hydroxyglycine, potential intermediates in the conversion of glycine to cyanide, were tested as substrates for cyanogenesis, but were inactive. However, $\mathrm{N}$-hydroxyglycine was a noncompetitive inhibitor of cyanogenesis from glycine. Cyanogenic activity was found principally in the particulate fraction, but a significant amount was also present in the supernatant fraction from high-speed centrifugation. The activity in the particulate fraction was solubilized with detergents.
\end{abstract}

\section{INTRODUCTION}

Cyanide production has recently been studied in growing cultures of Chromobacterium violaceum and in intact, harvested bacteria (Rodgers \& Knowles, 1978; Collins et al., 1980; Nazly et al., 1981). Cyanide is formed by decarboxylation of glycine (Michaels et al., 1965). Methionine stimulates cyanogenesis by growing cultures (Michaels \& Corpe, 1965; Rodgers \& Knowles, 1978). Cyanogenesis by $C$. violaceum has the typical properties of secondary metabolite formation (see Weinberg, 1971, 1977; Drew \& Demain, 1977; Demain et al., 1979); cyanide is produced only during a short period at the end of exponential growth and its level of synthesis depends on the iron and phosphate content of the medium (Rodgers \& Knowles, 1978). Although differing in detail, similar data have been obtained for a Pseudomonas sp. (Wissing, 1974, 1975) and Pseudomonas aeruginosa (Castric, 1975, 1981). Harvested C. violaceum forms cyanide from glycine, but there is little stimulation by methionine (Nazly et al., 1981). The ability of harvested bacteria to form cyanide depends on the time of harvesting, but is little affected by the growth conditions, though addition of glycine itself to the growth medium may cause a slight decrease in this capacity (Nazly et al., 1981).

In order to study cyanogenesis by $C$. violaceum in more detail, a cell-free system was required. This paper reports a method for obtaining cyanide-producing extracts, how the activity of cyanogenesis varies in extracts derived from bacteria harvested at various stages of growth, and how the activities are affected by metabolites that could be involved in the catabolism of glycine to cyanide.

$\dagger$ Present address: School of Biological Sciences, National Institute for Higher Education, Dublin 9, Ireland.

Abbreviation: PMS, phenazine methosulphate. 


\section{METHODS}

Organism and growth conditions. Chromobacterium violaceum strain NCIB 9131 was grown on a minimal salts medium containing $10 \mathrm{mM}$-glutamate as the sole source of carbon and nitrogen (Rodgers \& Knowles, 1978). Where indicated, $2 \mathrm{~mm}$-glycine and $0.5 \mathrm{~mm}$-methionine were added to the medium.

Preparation of extracts. Bacteria were harvested by centrifugation at $20000 \mathrm{~g}$ for $5 \mathrm{~min}$ at $4{ }^{\circ} \mathrm{C}$ and washed twice in $100 \mathrm{~mm}$-Tricine/ $\mathrm{NaOH}$ buffer $(\mathrm{pH} \mathrm{8.3)}$ containing $1 \mathrm{~mm}$-dithiothreitol. The bacteria were resuspended such that a 100 -fold dilution had an $A_{750}$ of 0.7 to 0.9 . They were sonicated $\left(4 \times 20 \mathrm{~s}\right.$ at $4{ }^{\circ} \mathrm{C}$, MSE sonicator model $150 \mathrm{~W}$ ), with $\mathrm{O}_{2}$-free $\mathrm{N}_{2}$ passed over the surface of the sonication vessel. Whole cells and debris were removed by centrifugation at $16000 \mathrm{~g}$ for $30 \mathrm{~min}$ at $4{ }^{\circ} \mathrm{C}$. The cell-free extract was separated into particulate and supernatant fractions by centrifugation at $150000 \mathrm{~g}$ for $90 \mathrm{~min}$ at $4{ }^{\circ} \mathrm{C}$. The particulate fraction was suspended in $100 \mathrm{~mm}$ Tricine/ $\mathrm{NaOH}$ buffer ( $\mathrm{pH} \mathrm{8.3)} \mathrm{containing} 1 \mathrm{~mm}$-dithiothreitol. Extracts were stored before assay by flushing storage vials with $\mathrm{N}_{2}$, sealing and freezing at $-15^{\circ} \mathrm{C}$.

Determination of cyanide production. Cyanide formation by extracts and whole cells was determined in a Wissing apparatus (Wissing, 1975, 1981). Bacteria or extract, plus any other required reagents, were added in $50 \mathrm{~mm}$ Tricine/ $\mathrm{NaOH}$ buffer $(\mathrm{pH} 8.3$ ) to give a total volume of $1 \mathrm{ml}$. The reaction was initiated by addition of $0.1 \mathrm{ml}$ $10 \mathrm{~mm}$-glycine. Cyanide was removed by passing air over the surface of the stirred reaction mixture $\left(800 \mathrm{ml} \mathrm{min}^{-1}\right)$. The incubation temperature was $30^{\circ} \mathrm{C}$. The cyanide was trapped in $1 \mathrm{ml} 0.5 \mathrm{M}-\mathrm{NaOH}$, taking samples at $5 \mathrm{~min}$ intervals. Samples were neutralized with $0.5 \mathrm{ml} 1 \mathrm{M}-\mathrm{HCl}$ plus $0.5 \mathrm{ml} 200 \mathrm{mM}-\mathrm{KH}_{2} \mathrm{PO}_{4} / \mathrm{K}_{2} \mathrm{HPO}_{4}$ buffer ( $\mathrm{pH} \mathrm{7.0)}$ and assayed immediately by the method of Lambert (1975).

Other assays. The conversion of $\left[1{ }^{14} \mathrm{C}\right]$ glycine and $\left[2-{ }^{14} \mathrm{C}\right] \mathrm{glycine}$ to $\mathrm{HCN}$ and $\mathrm{CO}_{2}$ was assayed, after the products had been trapped in $1 \mathrm{ml} 0.5 \mathrm{M}-\mathrm{NaOH}$ by the method of Bunch \& Knowles (1980). Samples of the reaction mixture were chromatographed in butan-1-ol/water/acetic acid $(120: 50: 30$, by vol.) on Eastman cellulose thin-layer chromatography plates. The radioactivity in each spot, located using amino acids as standards, was measured by scraping from the plate into phase combining system scintillation fluid and counting in a scintillation counter.

Protein was assayed by the Lowry method using bovine serum albumin as a standard. The $\mathrm{O}_{2}$ content of $\mathrm{O}_{2} / \mathrm{N}_{2}$ mixtures was determined in an oxygen analyser (Taylor Servomix type OA 184).

Chemicals. $\left[1{ }^{-14} \mathrm{C}\right]$ Glycine $\left(56 \mathrm{mCi} \mathrm{mol}^{-1} ; 2.07 \mathrm{GBq} \mathrm{mol}^{-1}\right)$ and $\left[2{ }^{14} \mathrm{C}\right] \mathrm{glycine}\left(54 \mathrm{mCi} \mathrm{mol}^{-1}\right.$; $2 \cdot 03 \mathrm{GBq} \mathrm{mol}^{-1}$ ) were obtained from Amersham. Phase combining system was from Amersham Corp., Arlington Heights, Ill., U.S.A. N-Hydroxyglycine was kindly provided by Professor R. B. Beechey, Shell Research, Sittingbourne; TLC on Eastman cellulose plates, developed with butanone/tert-butyl alcohol/formic acid/ $\mathrm{H}_{2} \mathrm{O}$ $(40: 30: 15: 15$, by vol.) yielded only one spot when detected with dimethylaminobenzaldehyde in acidic ethanol. The m.p. of $N$-hydroxyglycine was $130^{\circ} \mathrm{C}$, which agrees with previous data (Cooper \& Griffith, 1979). Phenazine methosulphate (PMS) was obtained from Sigma. Whenever possible, all other reagents were of analytical grade; glass-distilled water was used throughout.

\section{RESULTS}

Maximum cyanide production by cell-free extracts of $C$. violaceum required the presence of dithiothreitol during preparation of the extracts; the optimum concentration was $1 \mathrm{~mm}$. The presence of dithiothreitol during assay of the extracts was not necessary for maximal activity. Mercaptoethanol, cysteine and glutathione were less effective than dithiothreitol. Although strictly anaerobic conditions were not found to be essential during preparation of extracts, maximal cyanogenic activity was obtained when preparative steps were carried out, wherever possible, in the presence of $\mathrm{O}_{2}$-free $\mathrm{N}_{2}$.

The products of cyanogenesis $\left(\mathrm{HCN}\right.$ and $\left.\mathrm{CO}_{2}\right)$ are more oxidized than the substrate, glycine. Since only a low level of cyanogenesis was observed under aerobic assay conditions, the addition of an exogenous electron acceptor was required. Potential natural electron acceptors $\left(\mathrm{NAD}^{+}\right.$, $\mathrm{NADP}^{+}, \mathrm{FAD}, \mathrm{FMN}, \mathrm{FAD}+\mathrm{FMN}$, mammalian cytochrome $c$, dihydrofolate) were ineffective. A range of redox dyes (PMS, phenazine ethosulphate, 2,6-dichlorophenolindophenol, tetrazolium blue, menadione, anthroquinone-2-sulphate, ubiquinone-9, $N, N, N^{\prime}, N^{\prime}-$ tetramethyl-p-phenylenediamine, 2-hydroxy-1,4-naphthoquinone, thionine, methyl viologen and potassium ferricyanide) were tested as electron acceptors. Of these, only PMS, phenazine ethosulphate and 2,6-dichlorophenolindophenol were effective. The activity of cyanide synthase in extracts was $0.25 \pm 0.17 \mathrm{nmol}$ cyanide $\min ^{-1}\left(\mathrm{mg}\right.$ protein) ${ }^{-1}$ (mean \pm S.D., 16 observations with separate extracts), using $1 \mathrm{~mm}$-glycine and $100 \mu \mathrm{M}$-PMS as substrates. The initial rate of cyanogenesis was proportional to the concentration of extract up to at least $20 \mathrm{mg}$ protein $\mathrm{ml}^{-1}$. 


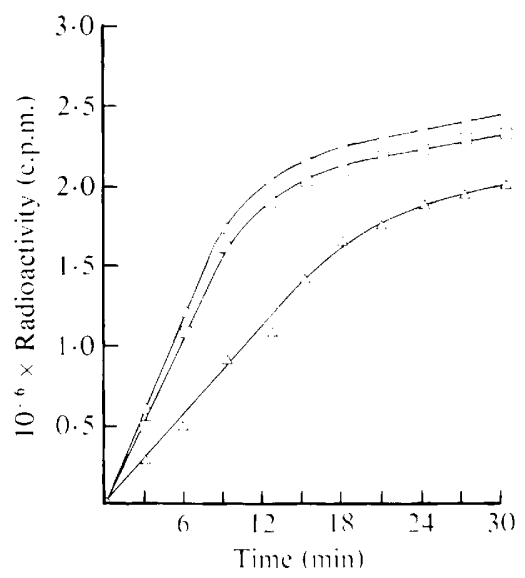

Fig. 1. $\mathrm{HCN}$ and $\mathrm{CO}_{2}$ production from $\left[1-{ }^{1+} \mathrm{C}\right]$ glycine and $\left[2-{ }^{14} \mathrm{C}\right]$ glycine by cell-free extracts. Extracts $\left(6 \mathrm{mg}\right.$ protein $\left.\mathrm{ml}^{-1}\right)$ were incubated in the presence of $\left[1^{-14} \mathrm{C}\right] \mathrm{glycine}\left(1 \mathrm{mM}, 9 \cdot 17 \mu \mathrm{Ci}_{\left.\mu \mathrm{mol}^{-1}\right)}\right.$ or $[2-$ ${ }^{14} \mathrm{Clglycine}\left(1 \mathrm{mM}, 8.3 \mu \mathrm{Ci} \mu \mathrm{mol}^{-1}\right)$ and $100 \mu \mathrm{M}-\mathrm{PMS}$ in $50 \mathrm{~mm}$-Tricine/ $\mathrm{NaOH}(\mathrm{pH} 8 \cdot 3)$. Total radioactivity recovered in the $\mathrm{NaOH}$ trap $(\mathrm{O})$, the $\mathrm{H}^{14} \mathrm{CN}$ from $\left[2-{ }^{14} \mathrm{C}\right] \mathrm{glycine}(\square)$ and the ${ }^{14} \mathrm{CO}_{2}$ from $\left[11^{14} \mathrm{C}\right]$ glycine $(\triangle)$ are recorded for a $30 \mathrm{~min}$ incubation.

Although phenazine ethosulphate gave about $20 \%$ greater activity than PMS, the latter was used routinely in further experiments since it gave more consistent results. The activity with 2,6dichlorophenolindophenol was about $80 \%$ of that with PMS. There was no further stimulation of activity by adding FMN and/or FAD in the presence of PMS as the electron acceptor.

With $100 \mu \mathrm{M}$-PMS as the electron acceptor the initial rate of cyanogenesis and the total amount of cyanide produced under anaerobic conditions were the same as in the presence of air. When the concentration of $\mathrm{O}_{2}$ was between $0 \cdot 1 \%$ and $0 \cdot 2 \%\left(\mathrm{v} / \mathrm{v}\right.$ with $\left.\mathrm{N}_{2}\right)$ the amount of cyanide produced was nearly doubled. Similar results were observed in the absence of PMS, although the amount of cyanide produced was very low.

The sensitivity of the cyanide synthase system to $\mathrm{O}_{2}$ was further studied by exposing the extract to a stream of air in the assay vessel prior to initiating cyanogenesis by addition of PMS or glycine. After 3 min exposure to air in the presence of PMS, $45 \%$ activity was lost. Aeration in the presence of glycine, but not PMS, prevented loss of any activity for $11 \mathrm{~min}$.

The apparent Michaelis constant for glycine was $300 \mu \mathrm{M}$ in the presence of $100 \mu \mathrm{M}$-PMS. Higher concentrations of PMS resulted in less cyanide formation. Extracts prepared in 100 or $50 \mathrm{mM}$-Tris/HCl, $100 \mathrm{~mm}-\mathrm{KH}_{2} \mathrm{PO}_{4} / \mathrm{K}_{2} \mathrm{HPO}_{4}, 25 \mathrm{~mm}$-HEPES/HCl or $25 \mathrm{~mm}$-PIPES/HCl buffers (all at $\mathrm{pH} 8.3$ and in the presence of $1 \mathrm{~mm}$-dithiothreitol) had less than $50 \%$ of the activity of extracts prepared in $100 \mathrm{~mm}$-Tricine $/ \mathrm{NaOH}(\mathrm{pH} 8 \cdot 3)$ plus 1 mM-dithiothreitol. In each case there was a wide $\mathrm{pH}$ optimum between $\mathrm{pH} 7 \cdot 5$ and $\mathrm{pH} 8 \cdot 3$.

Dialysis of extracts overnight against buffer under anaerobic conditions resulted in no loss of activity. Nevertheless the requirement for cofactors was investigated. No stimulation of activity was found on addition, singly or in combination, of $10 \mathrm{~mm}-\mathrm{NADP}^{+}, 10 \mathrm{~mm}-\mathrm{NAD}^{+}, 5 \mathrm{~mm}-\mathrm{ATP}$, $5 \mathrm{~mm}$-ADP, $10 \mathrm{~mm}-\mathrm{MgSO}_{4}, 1 \mathrm{~mm}$-pyridoxal phosphate or $1 \mathrm{~mm}$-tetrahydrofolate. Methionine $(0.5 \mathrm{mM}), \mathrm{Fe}^{3+}(30 \mu \mathrm{M})$ or $\mathrm{K}_{2} \mathrm{HPO}_{4}(10 \mathrm{mM})$, which maximally stimulated cyanogenesis by growing cultures (Rodgers \& Knowles, 1978), had no effect on the amount of cyanide formed or the rate of cyanogenesis from glycine by cell-free extracts.

Figure 1 shows total radioactivity, $\mathrm{H}^{14} \mathrm{CN}$ and ${ }^{14} \mathrm{CO}_{2}$ trapped during assay of extracts using either $\left[11^{-14} \mathrm{C}\right] \mathrm{glycine}$ or $\left[2{ }^{-14} \mathrm{C}\right] \mathrm{glycine}$ as substrate. The amount of ${ }^{14} \mathrm{CO}_{2}$ produced from $(2-$ $\left.{ }^{1+} \mathrm{C}\right]$ glycine and $\mathrm{H}^{14} \mathrm{CN}$ from $\left[1-{ }^{14} \mathrm{C}\right]$ glycine are not recorded as they accounted for less than $5 \%$ and $7 \%$, respectively, of the total radioactivity recovered. The carbon of $\mathrm{HCN}$ was derived from the $\mathrm{C}-2$ group of glycine and the carbon of $\mathrm{CO}_{2}$ from the carboxyl group of glycine. During the course of the assay the rate of trapping of the total radioactivity, $\mathrm{H}^{14} \mathrm{CN}$ and ${ }^{14} \mathrm{CO}_{2}$ was 


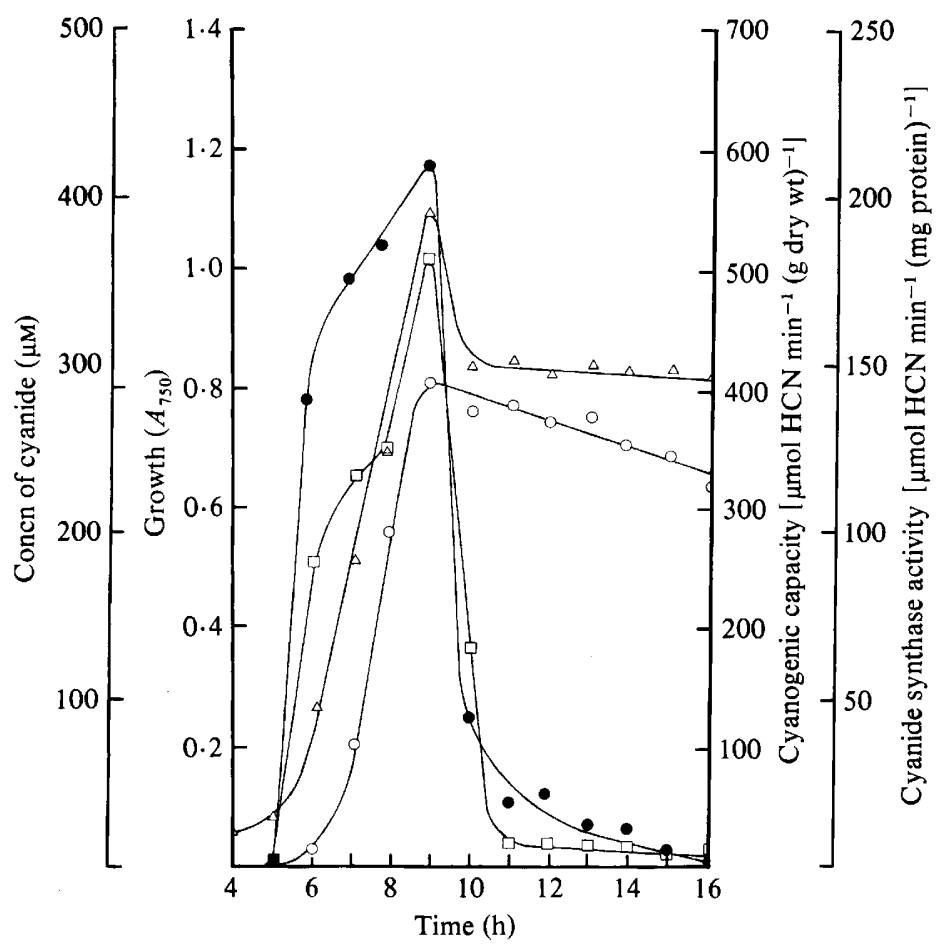

Fig. 2. Effect of growth phase on cyanogenic capacity and activity of cyanide synthase by extracts. Chromobacterium violaceum was grown on the $10 \mathrm{~mm}$ glutamate/minimal salts medium containing $2 \mathrm{~mm}$-glycine and $0.5 \mathrm{~mm}$-methionine. Cyanide formation by harvested bacteria and cell-free extracts was measured as described in Methods, with $10 \mathrm{mM}$-glycine as the substrate and, in the extracts, $100 \mu \mathrm{M}$-PMS as the electron acceptor. $\triangle$, Growth; $O$, cyanide content of the medium; $\square$, cyanogenic capacity of harvested bacteria;, cyanide synthase activity of cell-free extracts.

constant for $9 \mathrm{~min}$ and then declined. This decrease in activity with time could not be prevented by the addition of more glycine, PMS or dithiothreitol, or any of the compounds given above. In addition, the protease inhibitor phenylmethylsulphonyl fluoride, catalase, superoxide dismutase or the use of $\mathrm{O}_{2}$-free $\mathrm{N}_{2}$ instead of air did not prevent this time-dependent loss of activity. The slower apparent rate of release of $\mathrm{CO}_{2}$ than $\mathrm{HCN}$ from glycine was due to the lower rate of scavenging of $\mathrm{CO}_{2}$ from the Wissing apparatus (Wissing, 1975, 1981) rather than the efficiency of trapping.

The cyanide synthase system was found primarily in the particulate fraction, suggesting that it is membrane bound. However, a significant amount of activity (up to $40 \%$ of the total) was also recovered in the high-speed supernatant fraction, and this was not precipitated by further centrifugation. Total recovery of activity following high-speed centrifugation was variable, from 50 to $100 \%$ of the applied activity. The reasons for this are not clear, but it is probably due to oxygen lability of the cyanide synthase. Density-gradient centrifugation of the supernatant fraction did not reveal any discrete bands of activity in the supernatant fraction. Treatment of the particulate fraction with detergents solubilized cyanogenic activity. The recovery of activity in the soluble fraction after treatment of $4.7 \mathrm{mg}$ protein (ml particulate fraction) ${ }^{-1}$ with $0.5 \%$ (w/v) Lubrol PX, Nonidet P-40, Renex 690, SDS and Triton X-100 was $92 \%, 80 \%, 89 \%, 51 \%$ and $60 \%$, respectively.

Several potential inhibitors of cyanide formation from glycine by the extract were tested. EDTA (1 mM) caused a slight stimulation, whereas relatively high concentrations of monovalent and divalent metals $\left(7 \mathrm{~mm}-\mathrm{CaCl}_{2}, 50 \mathrm{mM}-\mathrm{KCl}, 50 \mathrm{~mm}-\mathrm{NaCl}, 50 \mathrm{~mm}-\mathrm{RbCl}, 50 \mathrm{~mm}-\mathrm{MgSO}_{4}\right.$, $\left.50 \mathrm{mM}-\mathrm{MgCl}_{2}\right)$ inhibited activity by about a third to a half; $\left(\mathrm{NH}_{4}\right)_{2} \mathrm{SO}_{4}(100 \mathrm{mM})$ had little 
effect. The respiratory inhibitor antimycin A caused only slight inhibition, as did the ionophore valinomycin. Up to $50 \%$ inhibition was caused by carbonyl cyanide $m$-chlorophenylhydrazone, which is an inhibitor of oxidative phosphorylation. Because of the possible relationship of cyanide synthase to amino acid oxidases (Wissing, 1975; Knowles, 1976), the effect of benzoate, which inhibits the latter enzymes, was tested. At a high concentration $(30 \mathrm{mM})$ it caused $50 \%$ inhibition of cyanide synthesis.

Several intermediates of the pathway of conversion of glycine to cyanide have been proposed (Michaels et al., 1965; Conn, 1973, 1979, 1981; Wissing, 1974; Knowles, 1976). The stable intermediates, oxamic acid, formaldoxime and glyoxylic acid oxime (all at $10 \mathrm{~mm}$ ) did not act as substrates for cyanogenesis nor did they inhibit the conversion of glycine (10 mM) to cyanide. The addition of methionine $(0.5 \mathrm{~mm})$ with these compounds had no effect. Betaine, $N, N$ dimethylglycine, sarcosine, glycinamide and the methyl or ethyl esters of glycine (all at $10 \mathrm{mM}$ ) did not inhibit conversion of glycine $(10 \mathrm{mM})$ to cyanide. Although $N$-hydroxyglycine $(10 \mathrm{mM})$ did not act as a substrate for cyanogenesis, it was a non-competitive inhibitor for the conversion of glycine to cyanide, with $50 \%$ inhibition of activity at a 6 to $7 \mathrm{mM}$ concentration in the presence of $10 \mathrm{~mm}$-glycine.

The ability of harvested whole cells to produce cyanide from glycine, termed the cyanogenic capacity by Castric et al. (1979), was measured at various stages of growth on bacteria grown under conditions of high cyanide formation (Fig. 2). Cyanogenic capacity increased during growth to a maximum about $8.5 \mathrm{~h}$ after inoculation. Cyanogenic capacity was rapidly lost between 9 and $11 \mathrm{~h}$ after inoculation. The appearance and disappearance of cyanogenic capacity correlated with the activity of cyanide synthase in extracts. This suggests that the loss of activity observed in cultures was due to degradation of the enzyme rather than regulation of its activity or removal of cyanide from the medium by $\beta$-cyanoalanine synthase (Rodgers \& Knowles, 1978).

The cyanogenic capacity of whole cells or the activity of cyanide synthase in extracts was unaffected by the presence or absence of glycine and methionine in the growth medium, but if glycine alone was added a slight decrease in activity was observed.

\section{DISCUSSION}

Cyanide synthase of $C$. violaceum is relatively sensitive to oxygen. Partial protection is provided by glycine, which also protects cyanide synthase of $P$. aeruginosa (Castric et al., 1981). The enzyme from $C$. violaceum is also stabilized by dithiothreitol, suggesting that there is a thiol group at the active site. Wissing \& Andersen (1981) have shown a requirement for dithiothreitol during preparation of cyanide synthase from Pseudomonas strain C.

The distribution of the cyanide synthase of $C$. violaceum between the particulate and supernatant fractions following high-speed centrifugation suggests that the enzyme is membrane bound but relatively easily removed from the membrane. Wissing (1975) has also suggested that cyanide synthase of Pseudomonas strain C is membrane bound. Like the enzyme in C. violaceum it can also be solubilized by detergents (Wissing \& Andersen, 1981).

The cyanide synthase of Pseudomonas strain C and P. aeruginosa (Wissing, 1975; Castric et al., 1979), as well as $C$. violaceum can use PMS as an electron acceptor. A natural electron acceptor has yet to be found, but the location of the enzyme in the membrane suggests that it may be coupled to the respiratory system. An inhibitor of electron transport, an inhibitor of oxidative phosphorylation and an ionophore did not greatly affect cyanogenesis by extracts of $C$. violaceum. In contrast, the enzyme is sensitive to some monovalent and divalent ions. This is not due simply to an increase in ionic strength, since $100 \mathrm{mM}-\left(\mathrm{NH}_{4}\right)_{2} \mathrm{SO}_{4}$ did not inhibit the enzyme. Collins et al. (1980) noted a decrease in cyanogenesis by cultures in which glycine was the sole source of nitrogen compared to those containing both ammonia and glycine.

No evidence has been gained about intermediates involved in the conversion of glycine to cyanide. Although oxamic acid, formaldoxime, glyoxylic acid oxime and $N$-hydroxyglycine did not act as substrates, this does not rule them out as intermediates. For example, substrate channelling might occur as happens in plant cyanogenesis (Conn, 1979), or an electron/hydro- 
gen acceptor or donor might be required which is recycled when glycine is the substrate. The inhibition of cyanogenesis from glycine by $N$-hydroxyglycine possibly suggests that it is acting as a substrate analogue, though if this were the case it might be expected to be a competitive rather than a non-competitive inhibitor.

The appearance and disappearance of cyanide synthase activity during growth of $C$. violaceum corresponds well to the activities of the enzyme predicted from earlier indirect studies with growing cultures (Rodgers \& Knowles, 1978; Nazly et al., 1981). Similar data have been obtained with $P$. aeruginosa (Castric et al., 1979). This pattern of enzyme formation is typical of enzyme synthesis seen with other secondary metabolites, for example gramicidin (Matteo et al., 1975).

\section{REFERENCES}

Bunch, A. W. \& Knowles, C. J. (1980). Cyanide production and degradation during growth of the snow mould fungus. Journal of General Microbiology 116, 9-16.

Castric, P. A. (1975). Hydrogen cyanide, a secondary metabolite of Pseudomonas aeruginosa. Canadian Journal of Microbiology 21, 613-618.

CASTRIC, P. A. (1981). The metabolism of hydrogen cyanide by bacteria. In Cyanide in Biology, pp. 233 262. Edited by B. Vennesland, E. E. Conn, C. J. Knowles, J. Westley \& F. Wissing. London \& New York: Academic Press.

Castric, P. A., Ebert, R. F. \& Castric, K. F. (1979). The relationship between growth phase and cyanogenesis in Pseudomonas aeruginosa. Current Microbiology 2, 287-292.

Castric, P. A., Castric, K. F. \& Meganathan, R. (1981). Factors influencing the termination of cyanogenesis in Pseudomonas aeruginosa. In Cyanide in Biology, pp. 263-274. Edited by B. Vennesland, E. E. Conn, C. J. Knowles, J. Westley \& F. Wissing. London \& New York: Academic Press.

Collins, P. A., Rodgers, P. B. \& Knowles, C. J. (1980). The effect of growth conditions of cyanogenesis by Chromobacterium violaceum. Journal of General Microbiology 117, 73-80.

ConN, E. E. (1973). Biosynthesis of cyanogenic glycosides. Biochemical Society Symposia 38, 277 302.

CONN, E. E. (1979). The biosynthesis of cyanogenic glycosides. Naturwissenschaften 66, 28-34.

ConN, E. E. (1981). Biosynthesis of cyanogenic glycosides. In Cyanide in Biology, pp. 183-196. Edited by B. Vennesland, E. E. Conn, C. J. Knowles, J. Westley \& F. Wissing. London \& New York: Academic Press.

Cooper, A. J. L. \& Griffith, O. W. (1979). NHydroxyamino acids: irreversible inhibitors of pyridoxal 5'-phosphate enzymes and substrates of D- and L-amino oxidases. Journal of Biological Chemistry 254, 2748-2753.

Demain, A. L., Kennel, Y. M. \& Aharonowitz, Y. (1979). Carbon catabolite regulation of secondary metabolism. Symposia of the Society for General Microbiology 29, 163-185.

Drew, S. W. \& Demain, A. L. (1977). Effect of primary metabolites on secondary metabolism. Annual Review of Microbiology 31, 343-356.

K NOWLES, C. J. (1976). Microorganisms and cyanide. Bacteriological Reviews 40, 652-680.
Lambert, J. L., Ramasamy, J. \& Paukstelis, J. V. (1975). Stable reagents for the colorimetric determination of cyanide by modified König reactions. Analytical Chemistry 47, 916 918.

Matteo, C. C., Glade, M., Tanaka, A., Piret, J. \& Demain, A. L. (1975). Microbiological studies on the formation of gramicidin S synthetases. Biotechnology and Bioengineering 17, 129-142.

Michaels, R. \& CORPE, W. A. (1965). Cyanide formation by Chromobacterium violaceum. Journal of Bacteriology 89, 106-112.

Michaels, R., Hankes, L. V. \& CoRpe, W. A. (1965). Cyanide formation by nonproliferating cells of Chromobacterium violaceum. Archives of Biochemistry and Biophysics 111, 121-125.

NaZly, N., Collins, P. A. \& Knowles, C. J. (1981). Cyanide production by harvested Chromobacterium violaceum. In Cyanide in Biology, pp. 289-300. Edited by B. Vennesland, E. E. Conn, C. J. Knowles, J. Westley \& F. Wissing. London \& New York: Academic Press.

Rodgers, P. B. \& Knowles, C. J. (1978). Cyanide production and degradation during growth of Chromobacterium violaceum. Journal of General Microbiology 108, 261-267.

WeInBerg, E. D. (1971). Secondary metabolism: raison d"etre. Perspectives in Biology and Medicine 14, 565-577.

WEINBERG, E. D. (1977). Mineral element control of microbial secondary metabolism. In Microorganisms and Minerals, pp. 289-315. Edited by E. D. Weinberg. New York: Marcel Dekker.

Wissing, F. (1974). Cyanide formation from oxidation of glycine by a Pseudomonas species. Journal of Bacteriology 117, 1289-1294.

Wissing, F. (1975). Cyanide production from glycine by a homogenate from a Pseudomonas species. Journal of Bacteriology 121, 695-699.

Wissing, F. (1981). A small scale HCN transfer technique for the rapid assay of enzymatic HCN formation. In Cyanide in Biology, pp. 473-478. Edited by B. Vennesland, E. E. Conn, C. J. Knowles, J. Westley \& F. Wissing. London \& New York: Academic Press.

Wissing, F. \& Andersen, K. A. (1981). The enzymology of cyanide production from glycine by a Pseudomonas species. Solubilization of the enzyme. In Cyanide in Biology, pp. 275-288. Edited by B. Vennesland, E. E. Conn, C. J. Knowles, J. Westley \& F. Wissing. London \& New York: Academic Press. 